\title{
Water Treatment with Pulsed Plasmas Generated Inside Bubbles
}

\author{
Keisuke Sato Student Menber (Tokyo Institute of Technology) \\ Koichi Yasuoka Member (Tokyo Institute of Technology) \\ Shozo Ishii Member (Tokyo Institute of Technology)
}

Keywords : plasma in water, pulsed plasma, $\mathrm{OH}$ radical, water treatment

\section{Introduction}

Water treatment technology has been developed using ozone. Ozone is an effective oxidant for water treatment due to the high oxidation potential and the harmlessness to the environment. Recently, advanced oxidation technology is studied for effective utilization of $\mathrm{O}$ and $\mathrm{OH}$ radicals. The oxidation potentials of these radicals are higher than that of ozone, and they can decompose persistent organics, such as dioxin, which cannot be decomposed by ozone. The lifetimes of these radicals are very short, and that makes it hard to utilize these radicals. Up to now, $\mathrm{OH}$ radicals are generated in water though the reaction between ozone and UV light or ozone and hydrogen peroxide $\left(\mathrm{H}_{2} \mathrm{O}_{2}\right)$. For more effective generation of $\mathrm{OH}$ radicals, direct generation methods using plasma are widely researched. We have studied a DC driven micro hollow cathode discharge operated in water with fast flow of oxygen and demonstrated the decomposition persistent materials in water. In this report, a parallel generation of pulsed plasma inside bubbles is investigated by applying fast rising voltage to the multi electrode system in treat water for improving the decomposition efficiency of persistent materials.

\section{Experimental Set-up}

The apparatus is schematically described in Fig.1. The electrode consisted of a dielectric plate (alumina) with a very small hole and a metal electrode (stainless steel). The thickness of the dielectric plate is $1 \mathrm{~mm}$, and the diameter of the discharge hole was $0.2 \mathrm{~mm}$. In the parallel discharge system, a dielectric plate with nine small holes (diameter: $0.2 \mathrm{~mm}$ ) is used. Water above the electrode was grounded.

Oxygen (99.9\%) gas or Argon (99.999\%) gas was supplied through the narrow gap at the electrode and its flow rate was

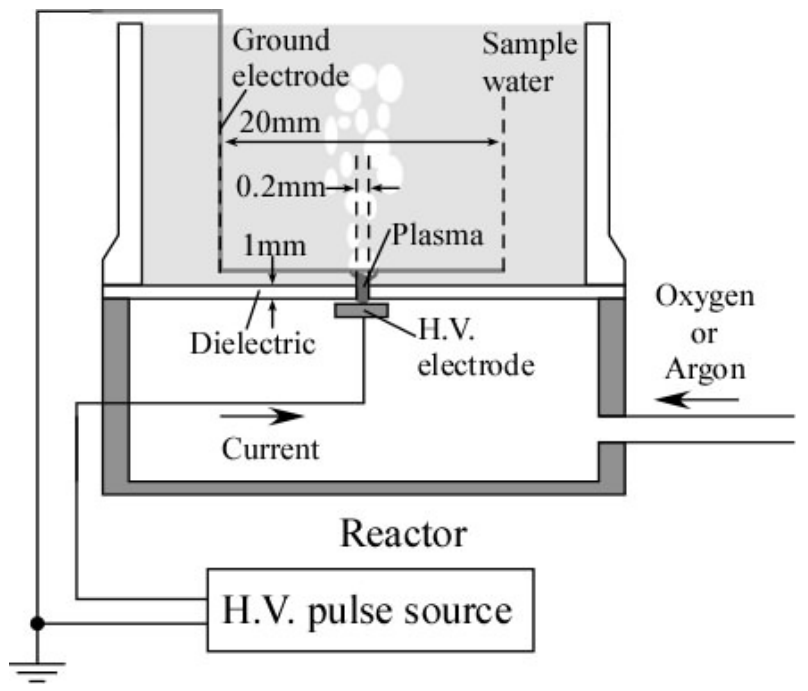

Fig. 1. Experimental setup controlled by a mass flow controller. The H.V. pulsed source consists of a DC power supply, an energy storage capacitor of $4.2 \mathrm{nF}$ and a Transistor switch.

Acetic acid $\left(\mathrm{CH}_{3} \mathrm{COOH}\right)$ solution was used as a persistent organic. Total organic carbon (TOC) concentration was measured by TOC analyzer (Sievers 810 ) for detecting the decomposition of acetic acid. Initial TOC concentration was $10 \mathrm{ppm}$, and the volume of sample water was $10 \mathrm{~mL}$.

\section{Result}

Decomposition rate and efficiency as a function of input power are fhown Fig.2 and Fig.3. Both the decomposition rate and efficiency in nine parallel discharges are higher than those in single discharge for same input power. The maximum values of decomposition rate of $19.8 \mu \mathrm{g} / \mathrm{min}$ and efficiency of 0.35 $\mathrm{g} / \mathrm{kWh}$ were obtained with the nine parallel discharge system. This efficiency is over 40 times larger compared with the single DC discharge system.

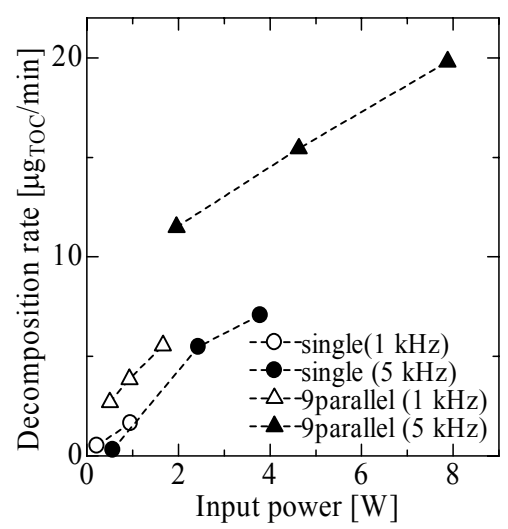

Fig. 2. Decomposition rate as a function of input power

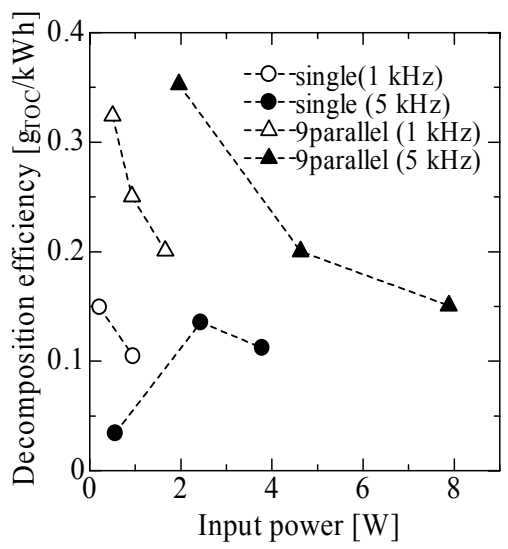

Fig. 3. Decomposition efficiency with power 


\section{水中気泡内パルスプラズマによる水処理

\author{
学生員 佐藤 圭輔* 正 員 安岡 康一* \\ 正 員 石井 彰三*
} \\ Water Treatment with Pulsed Plasmas Generated Inside Bubbles \\ Keisuke Sato*, Student Member, Koichi Yasuoka*, Member, Shozo Ishii*, Member

\begin{abstract}
Parallel operation of pulsed plasma generated inside bubbles is successfully demonstrated by applying fast rising voltage to a multi electrode system mounted in treat water. A $10 \mathrm{ppm}$ acetic acid which is not decomposed by ozone is used as persistent materials in water and the decomposing efficiency of that material is evaluated by measuring TOC values in water. The electric conductivity of treat water affects the decomposing efficiency because the water resistor that is inversely proportional to the conductivity limits the plasma current flowing along the surface of bubbles that are generated by feeding oxygen gas. With nine parallel electrode system, the decomposing efficiency of acetic acid shows higher values than that with a single electrode system. The emission of $\mathrm{OH}$ radicals generated in plasma was observed by spectroscopic measurements.
\end{abstract}

論 文

キーワード : 水中プラズマ, パルス, $\mathrm{OH}$ ラジカル, 水処理

Keywords : plasma in water, pulsed plasma, $\mathrm{OH}$ radical, water treatment

\section{1. はじめに}

プラズマにより生成されるオゾンは, 高い酸化力と低環 境負荷の両面から塩素に代わる酸化剤として水処理等の分 野に用いられている。しかしながら，オン゙ンの酸化力は有 機物を完全に分解するには不足するため，ダイオキシンな ごの難分解物質は処理できない。このため難分解物質も処 理可能な, オゾン以上の酸化効果の得られる高度水処理方 式が必要となっている。

オゾンを上回る酸化電位を持つ物質として O ラジカルや $\mathrm{OH}$ ラジカルがあるが, 中でも $\mathrm{OH}$ ラジカルは活性酸素中で 最も強力な酸化力をもつ。しかしラジカル寿命は数百 $\mu \mathrm{s}$ 以 下とされているため, 生成と同時に利用しなければならず, 効率的な利用を困難なものとしている。現在実用化されて いる高度水処理の方法としては, 処理水へのオゾン注入に 過酸化水素の添加や紫外線の照射などを組夕合わせて, 水 中で $\mathrm{OH}$ ラジカルを生成する方式がある。このようなオゾン を介した間接的な生成法以外に，放電による直接的なラジ カル生成方式も研究されている。酸素放電により $\mathrm{O}$ ラジカ ルは生成されるが, 水分子が存在していればさらに OH ラジ カルが生成される(1)。

これまでに報告されている $\mathrm{OH}$ ラジカルの直接生成方式

* 東京工業大学 電気電子工学専攻

T152-8552 東京都目黒区大岡山 2-12-1

Department of Electrical and Electronic engineering, Tokyo Institute of Technology

2-12-1, O-okayama, Meguro-ku, Tokyo 152-8552
として, 水中においた電極から水中ストリーマ放電を発生 させる方法 ${ }^{(2)(3) や, ~}$ 泡の内部で放電を起こす方法 ${ }^{(4)(5)}$, 水面 近傍で放電させて水中へ $\mathrm{OH}$ ラジカルを送り込む方法 ${ }^{(6)(7)}$ どがある。

筆者らはこれまで水中の数百 $\mu \mathrm{m}$ の微小な穴があいたア ルミナに直流高電圧を印加することによりマイクロプラズ マを生成し, 水とプラズマを直接反応させる方式を採用し 実験を行ってきた ${ }^{(8)}$ 。その結果, ラジカルによる難分解物質 処理が可能になった。しかしながらこの方式では直流電圧 を使用しているため, 水の電気分解に加えて放電維持に高 い投入電力が必要であり, 分解効率の向上が課題だった。

本研究では直流電圧の代わりに高速パルス電圧を印加す ることにより, 電気分解の抑制と同時に, 多数の水中気泡 内で同時にパルスプラズマを形成し，放電面積の拡大と， 電極 1 つあたりの投入電力を抑制する方式を提案する。こ の方式の特徴を挙げると以下のようになる。

（1）水のごく近傍で $\mathrm{OH}$ ラジカルを生成することが可 能。

（2）誘電体の微小な穴で放電するため, 比較的低電圧で 安定な放電が可能。

（3）水中放電であるため水面の影響を受けない。

（4）電極の並列化により放電面積の拡大が容易。

また処理対象としては難分解性物質として酢酸水溶液を 用いた。䣷酸は有機物としては低分子でありオゾン単体で は分解できない。一般的に酢酸が分解できれば多くの難分 
解性有機物を分解でき，高度水処理効果を確認できるとい われている(7)。

\section{2. 実験装置及び実験方法}

$\langle 2 \cdot 1\rangle$ 実験装置図 1 に実験装置の概略図を示す。 実験装置は放電が発生し水処理が行われるリアクタとパル ス電源から構成される。放電電極は, 厚さ $1 \mathrm{~mm}$ のアルミナ (Macor) に直径 $0.2 \mathrm{~mm}$ の微小な穴が 1 つある電極と 9 つあ る電極の 2 種類を用意した。どちらの電極も高電圧側電極 は厚さ $0.2 \mathrm{~mm}$ のステンレス製金属平板を使用し，アルミナ との間にガスを通過させるために約 $0.1 \mathrm{~mm}$ の隙間をあけて 接触させている。また接地電極は, 直径 $1 \mathrm{~mm}$ のステンレス 鋼線を直径 $20 \mathrm{~mm}$ のリング状にして水中に配置した。図 2 は並列放電用電極構造の概観図である。本論文では便宜上,

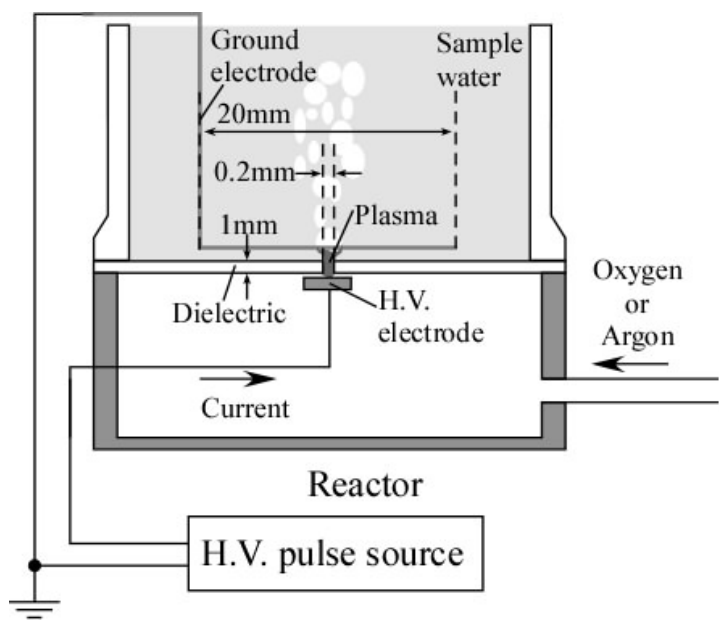

図 1 実験装置図

Fig. 1. Experimental setup

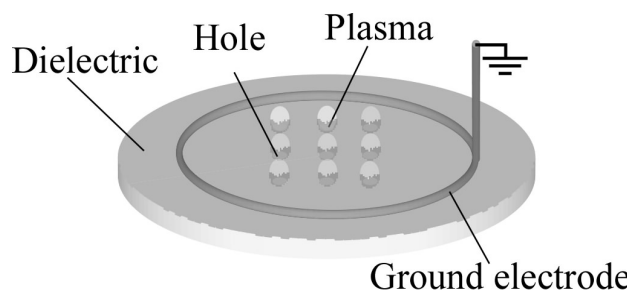

(a) Schematic diagram

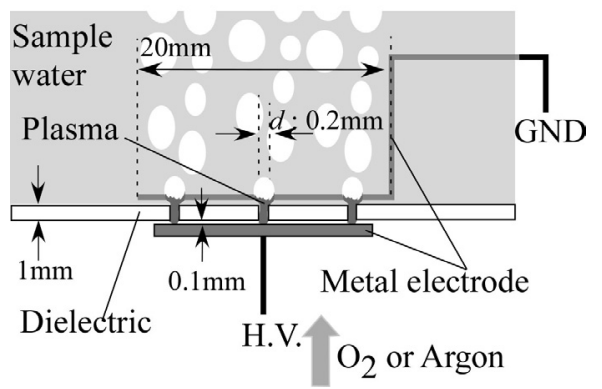

(b) Cross-sectional view

図 2 放電電極構造（9 並列電極）

Fig. 2. Schematic of the electrode configuration.

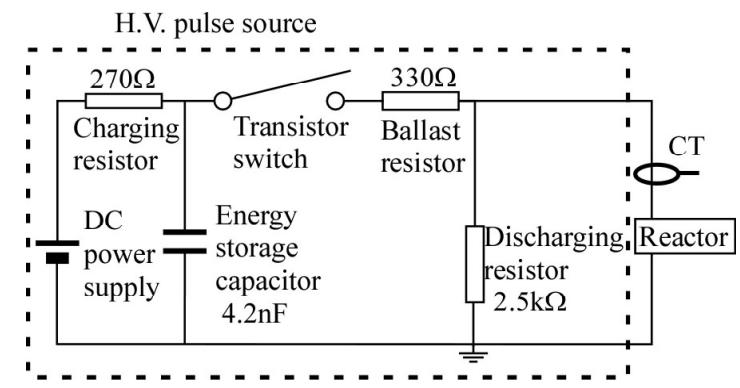

図 3 実験回路図

Fig. 3. Circuit schematic.

表 1 パルス電源の主な仕様

Table 1. Specification of H.V. pulse source.

\begin{tabular}{|c|c|}
\hline Max. Operating Voltage & $8 \mathrm{kV}$ \\
\hline Max. Peak Current & $30 \mathrm{~A}$ \\
\hline Rise time & $100 \mathrm{~ns}$ \\
\hline Max. Switching Frequency & $40 \mathrm{kHz}$ \\
\hline
\end{tabular}

微小な穴が 1 つの電極を 1 並列電極, 9 つの電極を 9 並列電 極と呼ぶこととする。

酸素（純度 99.9\%）またはアルゴン（純度 99.999\%）はマ スフローコントローラ（KOFLOC 3200）を介して流量制御 をしながら電極部へ供給した。これまでの研究から, 本方 式においてはガス流量と分解速度は依存しないこと, 寸べ ての穴にガスが満たされないと並列放電しないことが分か っているので, 放電開始に必要十分な流量を供給した。1 並 列時は $50 \mathrm{sccm} ， 9$ 並列時は $450 \mathrm{sccm}$ とした。

実験回路図を図 3 に示す。パルス電源は, 直流高圧電源(松 定プレシジョン製,HAR-30R40), 充電抵抗 $(270 \Omega)$, コンデ ンサ $(4.2 \mathrm{nF})$, 半導体スイッチ (BEHLKE, HTS81), 電流制 限抵抗 $(330 \Omega)$, 放電抵抗 $(2.5 \mathrm{k} \Omega)$ により構成され, 直流 電源から充電抵抗を介してコンデンサを充電し, 半導体ス イッチで高速スイッチングし, 高電圧電極に正極性のパル ス電圧を印加する。半導体スイッチはパルスジェネレータ （Stanford research system,DG535）で制御している。パルス電 源の主な仕様を表 1 に示す。電圧は高電圧プローブ （Tektronix,P6015A）により, 電流は CT（Pearson Electronics Inc., CT4100) により測定し, それぞれデジタルオシロスコ ープ（Tektronix, TDS644B）に波形を取り込んでいる。

処理水には酶酸 $\left(\mathrm{CH}_{3} \mathrm{COOH}\right)$ 水溶液を使用した。酢酸は 完全分解すると, $\mathrm{H}_{2} \mathrm{O}$ と $\mathrm{CO}_{2}$ となり処理水中の有機炭素濃 度が減少する。このため本実験では分解の効果を水中の全 有機炭素（total organic carbon; TOC）濃度を TOC 計（Sievers 810）により測定することで評価した。また測定に使用した 処理水の初期 TOC 濃度は $10 \mathrm{ppm}$ とし, 水量は $10 \mathrm{~mL}$ とし た。

\section{3. 実験結果および考察}

〈3·1〉放電特性 酸素ガスとアルゴンガスを使用し たときのリアクタへの印加電圧及びリアクタに流れる電流 
波形の代表例を図 4, 図 5 に示寸。波形は 10 パルスの平均 で，充電電圧は $8 \mathrm{kV}$ ，処理水の酶酸水溶液は導電率が 30 $\mu \mathrm{S} / \mathrm{cm}$ の精製水に䣷酸を混ぜた溶液と, $90 \mu \mathrm{S} / \mathrm{cm}$ の水道水 に酢酸を混ぜた溶液を用いた。導電率が高い水道水をもと にした䣷酸水溶液の方が，純水をもとにしたものよりも印 加電圧の立下りが早く，電流值が大きいことが分かる。図 中に ICCD カメラによって確認した処理水を流れる変位電 流と放電開始のタイミングを示す。放電開始電圧は酸素ガ スの $5 \mathrm{kV}$ に比ベアルゴンガスは $2 \mathrm{kV}$ と低く, アルゴンガス の放電電流は酸素ガスよりも大きいことがわかる。酸素ガ スは負性ガスであり，電子付着が起こり易いため放電維持 電圧が高く，均一な放電を維持するのが困難である。一方 で，希ガスであるアルゴンは電子付着が起こらない上に準

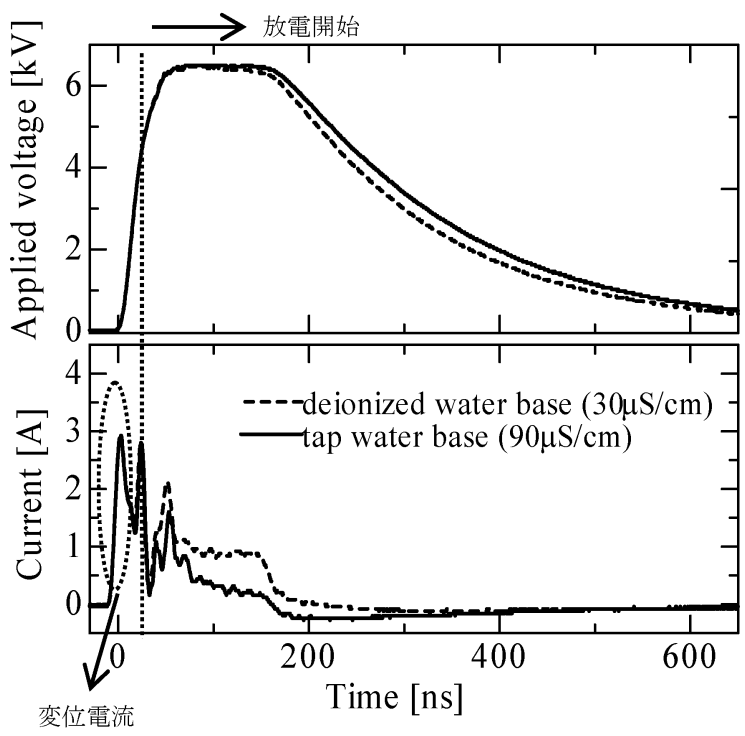

図 $4 \mathrm{O}_{2}$ 供給時の電圧電流波形

Fig. 4. Typical waveforms of single discharge with $\mathrm{O}_{2}$.

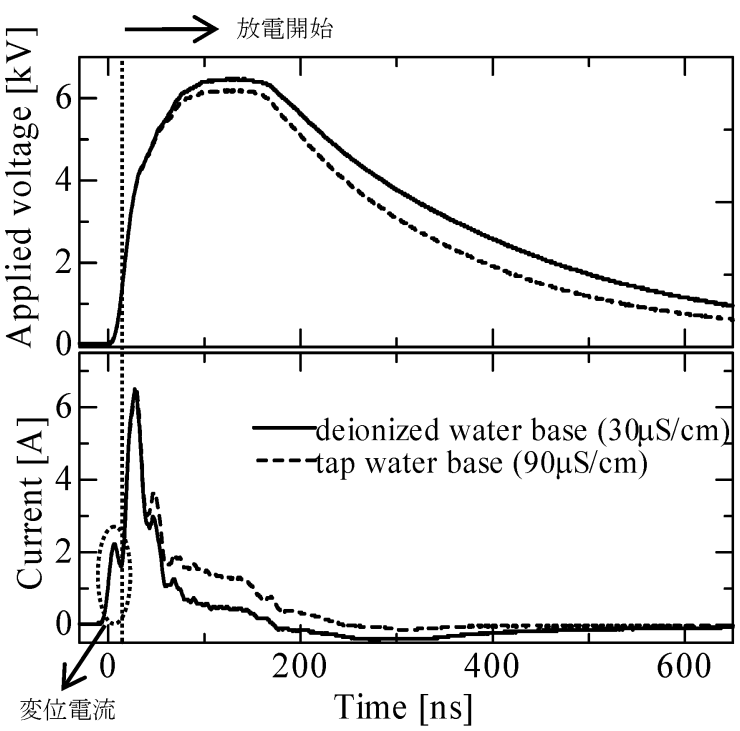

図 $5 \mathrm{Ar}$ 供給時の電圧電流波形

Fig. 5. Typical waveforms of single discharge with Ar.
安定原子により放電が維持されるために, 放電維持電圧が 低く均一な放電を形成しや寸い。これらの物理的理由から 図 4, 図 5 のような放電波形になったと考えられる。

電圧電流波形の積を時間積分寸ることによって, 1 パルス あたりの消費エネルギーを求めることができる。図 4 にお ける 1 パルスあたりの消費電力は, 精製水をもとにしたも のは $0.12 \mathrm{~mJ}$ ，水道水をもとにしたものは $1.16 \mathrm{~mJ}$ であり一 桁ほじ值が変化するのに対し, 図 5 のアルゴンガスの場合 は，精製水をもとにしたものは $1.26 \mathrm{~mJ}$ ，水道水をもとにし たものは $2.09 \mathrm{~mJ}$ と酸素ほどの大きな変化は見られなかっ た。

〈3·2〉放電スペクトル $\mathrm{OH}$ ラジカルの励起発光を 観測するため分光器 (Ocean Optics Inc,USB4000) による分 光計測を行った。放電により $\mathrm{OH}$ ラジカルが発生すると, 309 $\mathrm{nm}$ 付近のスペクトルが観測される。図 6 に酸素とアルゴン を用いて水道水をもとにした䣷酸水溶液を処理した場合の 発光スペクトル分布を示す。

図 6 から酸素とアルゴン共に $\mathrm{OH}$ ラジカル $(309 \mathrm{~nm}), \mathrm{O}$

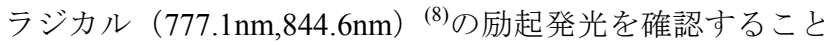
ができた。したがって水中で $\mathrm{OH}$ ラジカルや O ラジカルが 生成され, 表 2 に示す (1)〜 (3)式の反応が起こっていると 考えられる。

〈3・3〉酢酸分解特性に対する放電ガスと導電率の影響

本方式においては水を片側の電極としており，導電率の 違いによって 1 パルスあたりの消費エネルギーにも違いが 生じることから，処理水の導電率が分解特性に影響を与え る一つの要因であると考えた。そこで本実験では処理水で

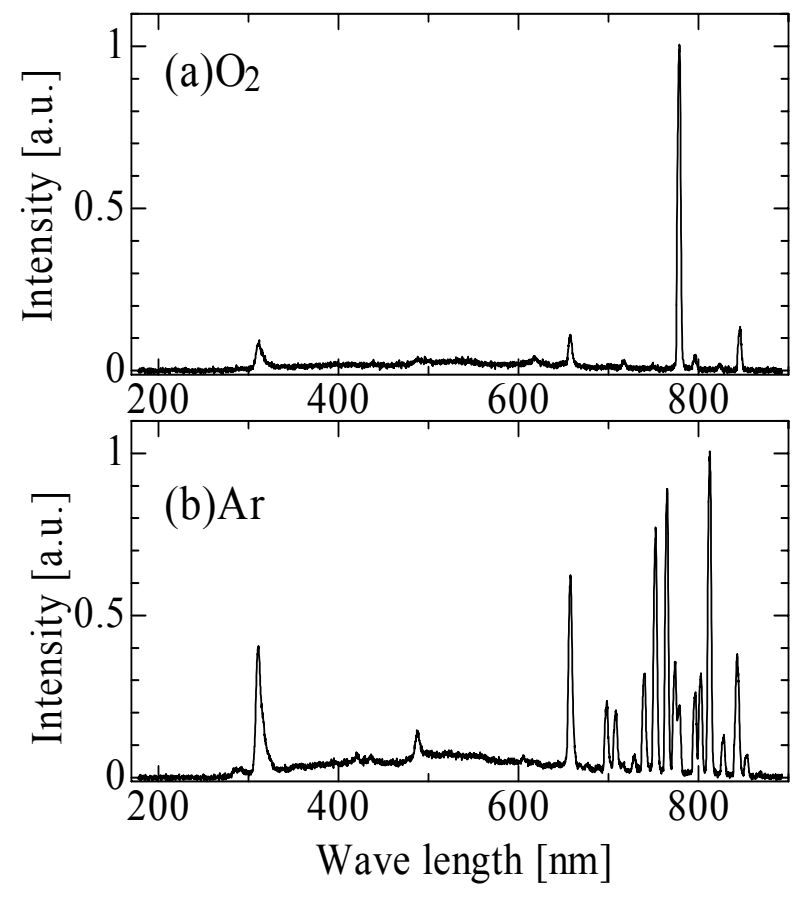

図 6 分光計測結果

Fig. 7. Spectrum distribution of plasma emission of $\mathrm{O}_{2}$ and Ar. 


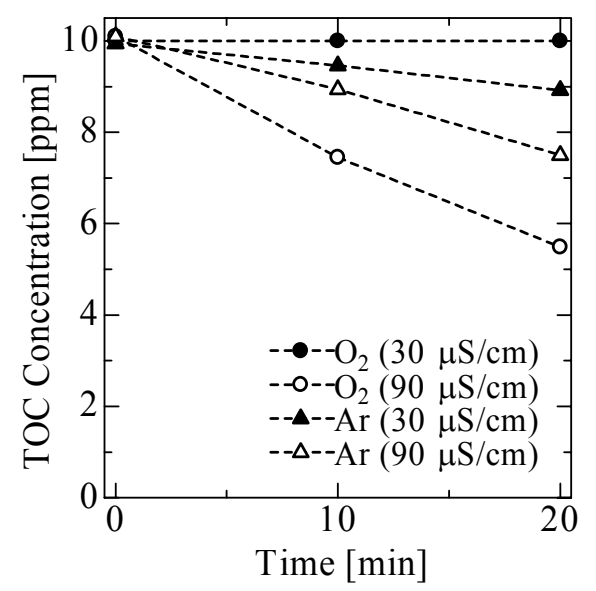

図 $7 \mathrm{O}_{2}$ と $\mathrm{Ar}$ を用いた場合の分解特性

Fig. 7. Time dependency of decomposition of acetic acid with two different electric conductivities in case of using $\mathrm{O}_{2}$ and Ar.

ある酢酸水溶液の導電率を $30 \mu \mathrm{S} / \mathrm{cm}$ である精製水をもとに したものと $90 \mu \mathrm{S} / \mathrm{cm}$ である水道水をもとにしたものの 2 種 類を用いて䣷酸分解を行った。図 7 に導電率を変化させた ときの酸素とアルゴンを用いた酢酸分解の時間的推移を示 す。実験条件は 1 並列電極, 充電電圧 $8 \mathrm{kV}$, 繰り返し周波 数 $3 \mathrm{kHz}$ である。このときの放電電圧・電流波形はそれぞれ 図 4, 図 5 と対応している。

結果から導電率が $30 \mu \mathrm{S} / \mathrm{cm}$ の場合, 酸素を用いたときは ほとんど酢酸を分解できなかったが，アルゴンでは酢酸を 分解することができた。また $90 \mu \mathrm{S} / \mathrm{cm}$ の場合, 酸素とアル ゴン共に䣷酸を分解することができ，分解量は酸素のほう が大きかった。䣷酸分子のオゾンとの反応速度定数は $3 \times$ $10^{-5} \mathrm{~mol}^{-1} \mathrm{~s}^{-1}$ であり ${ }^{(10)}$, 実際に放電させずに酸素のみを流し た場合やオゾンを注入した場合には TOC 濃度は減少しない ことは確認している(7)。また分光結果からも確認できた $\mathrm{OH}$ ラジカルの反応速度定数は $1.6 \times 10^{7} \mathrm{~mol}^{-1} \mathrm{~s}^{-1}$ であり ${ }^{(10)}$ 酢酸 分子の分解に働いているのは $\mathrm{OH}$ ラジカルであると考えら れる。

アルゴンの場合，処理水の導電率に関係なく放電が安定 して形成され，1 パルスあたりの消費エネルギーに大きな違 いは見られない。更にピーク電流值は $7 \mathrm{~A}$ 程度と酸素の $2 \mathrm{~A}$ よりも大きく, 瞬間的に( 1 )式の反応により大量に $\mathrm{OH}$ ラジ カルは生成されるが， (4)〜 (6) 式の反応により $\mathrm{OH}$ ラジカ ルが酢酸分子と反応する量も減少すると考えられる ${ }^{(11)}$ 。一 方で酸素の場合, 導電率が $90 \mu \mathrm{S} / \mathrm{cm}$ の処理水を用いると放 電電流は $1 \mathrm{~A}$ 程度が $200 \mathrm{nS}$ 程度継続していることが分かる。 (1)～( 3 )式の反応により $\mathrm{OH}$ ラジカルが生成されると共 に, OH ラジカルの消滅過程はアルゴンの場合と比べて減少 すると考えられる。

〈3.4〉9並列放電電極による放電特性 図 8 に 9 並列 電極を用いたときのリアクタへの印加電圧及びリアクタに 流れる電流波形の代表的なものを示す。波形は 10 パルスの 平均で, このときの実験条件は $\mathrm{O}_{2}$ ガス, 充電電圧 $8 \mathrm{kV}$, 繰
表 $2 \mathrm{OH}$ 生成と消滅に関する反応

Table 2. Important chemical reactions about $\mathrm{OH}$ radical ; The unit for a two-body reaction is $\mathrm{cm}^{3} \mathrm{~s}^{-1}$ and that for a three-body reaction is $\mathrm{cm}^{6} \mathrm{~s}^{-1}$.

\begin{tabular}{|c|c|c|c|}
\hline No. & Reaction & $k$ at $300 \mathrm{~K}$ & Reference \\
\hline (1) & $\mathrm{H}_{2} \mathrm{O}+\mathrm{e} \rightarrow \mathrm{OH}+\mathrm{H}+\mathrm{e}$ & $2.48 \times 10^{-10}$ & KINEMA \\
\hline (2) & $\mathrm{e}+\mathrm{O}_{2} \rightarrow \mathrm{O}+\mathrm{O}+\mathrm{e}$ & $4.12 \times 10^{-9}$ & $(12)$ \\
\hline (3) & $\mathrm{O}+\mathrm{H}_{2} \mathrm{O} \rightarrow \mathrm{OH}+\mathrm{OH}$ & $6.25 \times 10^{-11}$ & $(13)$ \\
\hline (4) & $\mathrm{OH}+\mathrm{OH}+\mathrm{M} \rightarrow \mathrm{H}_{2} \mathrm{O}_{2}+\mathrm{M}$ & $6.09 \times 10^{-31}$ & $(14)$ \\
\hline (5) & $\mathrm{OH}+\mathrm{OH} \rightarrow \mathrm{H}_{2} \mathrm{O}+\mathrm{O}$ & $1.80 \times 10^{-12}$ & (13) \\
\hline (6) & $\mathrm{OH}+\mathrm{H}+\mathrm{M} \rightarrow \mathrm{H}_{2} \mathrm{O}+\mathrm{M}$ & $6.78 \times 10^{-31}$ & $(15)$ \\
\hline
\end{tabular}

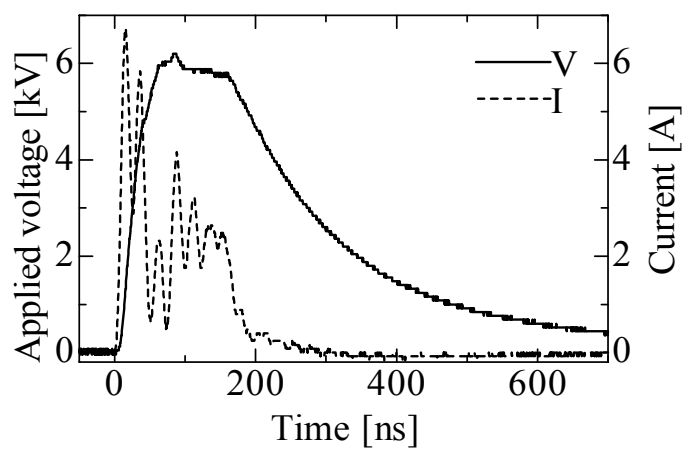

図 8 酸素供給, 9 並列電極電圧電流波形

Fig. 8. Typical waveforms of parallel discharge with $\mathrm{O}_{2}$.

り返し周波数 $1 \mathrm{kHz}$, 処理水は導電率が, $90 \mu \mathrm{S} / \mathrm{cm}$ の水道水 に䣷酸を混ぜた溶液を用いた。9 並列電極にすることで 1 並 列電極の同条件よりも電圧の立下りが早く, ピーク電流值 が大きいことがわかる。またこのときの 1 パルスあたりの 消費電力は $2.2 \mathrm{~mJ}$ であった。

図 9 に 9 並列放電の 1 パルスあたりの放電発光の様子を 示す。このときの放電条件は図 8 と同じで露光時間は $300 \mathrm{~ns}$ とした。写真から 9 つの穴す心゙てにおいて放電しているこ とが確認された。これまでの研究では直流電圧を印加して いるため電極を並列に配置しても放電が一箇所に集中し, 安定に複数の放電を並列につけることは困難であった。こ れは直流放電を維持するために, 電極 1 つあたり定常的に $40 \mathrm{~W}$ 程度の投入電力が必要で, 電極を並列化するとその分 だけ電極 1 つ当りの投入電力が減少し安定放電が困難にな るためであると考えられる。一方本研究では高速高電圧パ ルスを電極に印加しているため, 平均投入電力は数 $\mathrm{W}$ 程度 だが瞬間的には $12 \mathrm{~kW}$ 程度の高い電力を放電部に注入して おり電極を複数に並べてもすべての電極において安定な放 電が形成することが可能になったと考えられる。

〈3.5〉9並列放電電極による酢酸分解特性 図 10 に 1 並列電極と 9 並列電極を用いたときの印加電圧と消費電力 の関係を示す。結果から印加電圧の増加に比例して消費電 力が増加していることが分かる。また同じ繰り返し周波数 では, 9 並列電極のほうが 1 並列電極よりも消費電力は大き いが，単純に 9 倍ではないことから，9 並列電極の放電ひと 


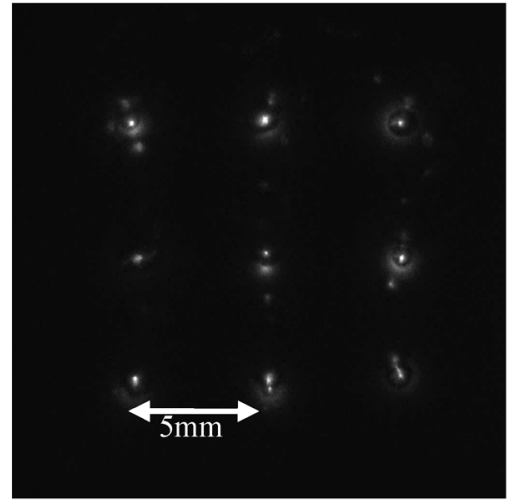

Charging voltage : $8 \mathrm{kV}$, Pulse repetition rate : $1 \mathrm{kHz}$, Exposure time : $300 \mathrm{~ns}$

図 9 酸素ガス供給, 9 並列放電の静止写真

Fig. 9. Still photograph of parallel discharge with $\mathrm{O}_{2}$.

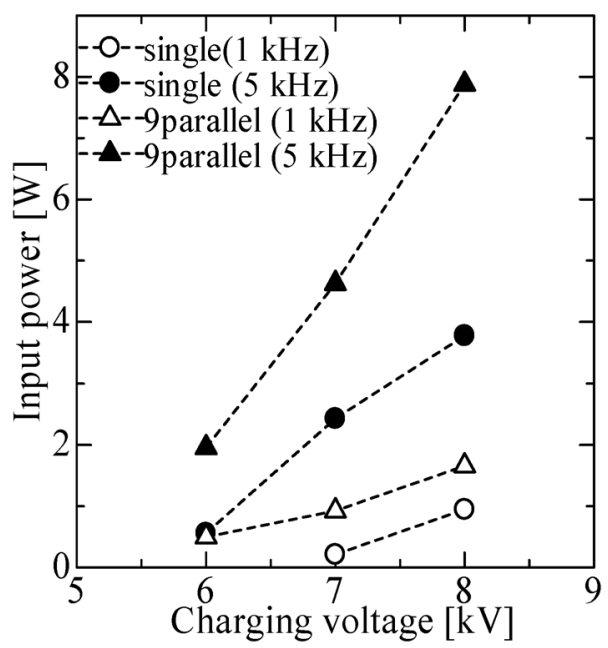

図 10 印加電圧と消費電力の関係

Fig. 10. Relationship between input power and charging voltage.

つ当りの平均消費電力は, 1 並列電極のそれよりも低いこと が考えられる。

図 11 に消費電力に対する分解速度の変化を示す。図 11 において分解速度は(4)式を使って求めた。

$$
\eta_{t}=\frac{\Delta C \cdot w}{\Delta t}
$$

ここで $\eta_{t}\left[\mathrm{~g}_{\mathrm{TOC}} / \mathrm{min}\right]$ は単位時間当たりの分解量, $\Delta C[\mathrm{ppm}]$ は TOC 減少分, $w[\mathrm{~g}]$ は処理水量, $t[\mathrm{~min}]$ は処理時間である。 結果から消費電力に比例して分解速度が増加していること が分かる。消費電力量に比例して放電電流が増加すること により, プラズマの電子数密度が増加し(1)〜(3)式の反応 による $\mathrm{OH}$ ラジカル生成が促進されるためであると考えら れる。また繰り返し周波数を増加させると生成される $\mathrm{OH}$ ラジカル量も増加するため, 䣷酸の分解速度は増加してい る。

図 12 に消費電力に対する分解エネルギー効率の変化を示 す。酢酸分解エネルギー効率は, (4)式で求めた分解速度を

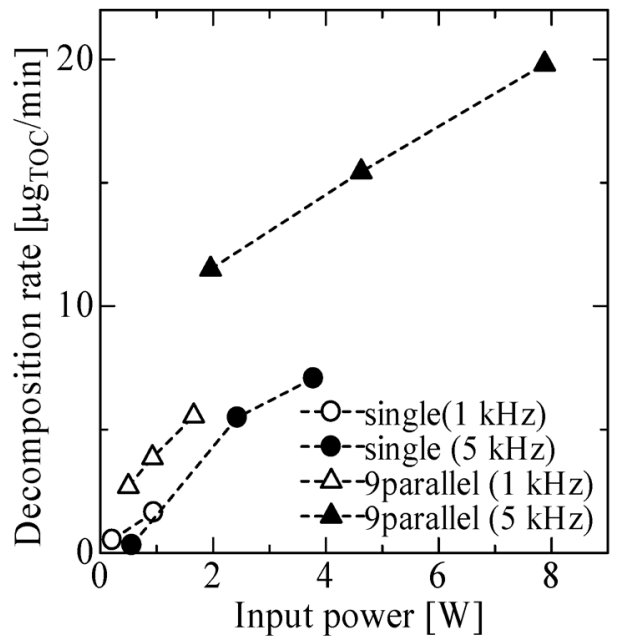

図 11 消費電力に対する分解速度の変化

Fig. 11. Decomposition rate as a function of input power.

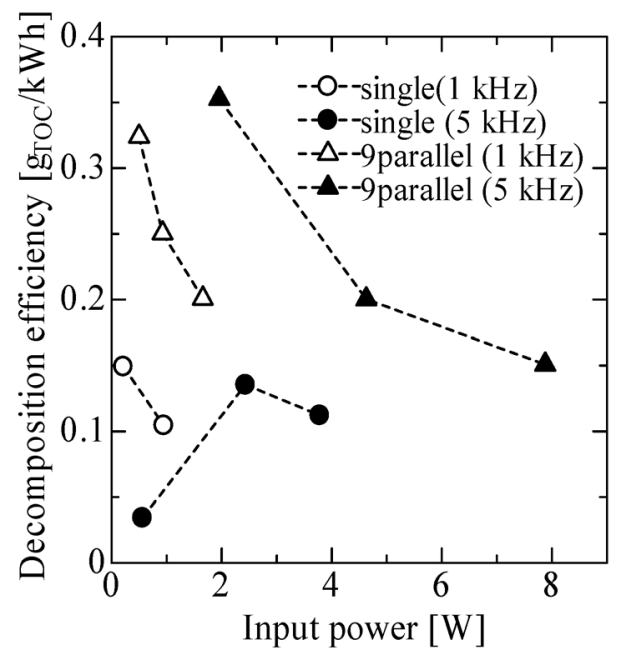

図 12 消費電力に対する分解エネルギー効率の変化 Fig. 12. Decomposition efficiency with power.

用いて, (5)式で求めた。

$$
\eta_{e}=\frac{\Delta C \cdot w}{f \int V \cdot I d t}
$$

$\eta_{e}\left[\mathrm{~g}_{\mathrm{TOC}} \mathrm{kWh}\right]$ は単位エネルギーあたりの分解量, $f[\mathrm{~Hz}]$ はパ ルス繰り返し周波数, $V[\mathrm{~V}]$ は印加電圧, $I[\mathrm{~A}]$ は放電電流で ある。図 12 から分解エネルギー効率は消費電力が大きくな ると減少する傾向にあることが分かる。これは投入される 電力が大きくなると, 生成される $\mathrm{OH}$ ラジカルの量が増加 し，(4)〜(6)式で示されるように䣷酸分子と反応する前に $\mathrm{OH}$ ラジカル同士での反応が進みエネルギー損失が大きく なるためであると考えられる ${ }^{(11)}$ 。エネルギー効率は繰り返 し周波数によってあまり変化しないことから, 周波数が増 加したことによる $\mathrm{OH}$ ラジカルの損失はほとんど無いと言 える。1 並列電極の繰り返し周波数 $5 \mathrm{kHz}$ の放電で投入電力 が最小のとき効率は減少しているが，これは充電電圧が 6 
$\mathrm{kV}$ のとき安定な放電を維持することができなかったためで あると考えられる。

図 11 と図 12 で 1 並列電極と 9 並列電極を比較すると, 分解速度, 分解エネルギー効率共に 9 並列電極のほうが優 れていることが分かる。同じ投入電力で，放電が並列に発 生している場合, 電極 1 つ当りの平均電力は 9 並列の方が 少ないため, 上述した $\mathrm{OH}$ ラジカル同時のエネルギー損失が 減少し，1 パルスあたりに生成される $\mathrm{OH}$ ラジカルの酢酸分 子と反応する割合が増加する。したがって電極を並列化す ることによって放電 1 つ当りの投入電力を抑制し, 分解速 度，分解エネルギー効率が上昇したと考えられる。

\section{4. まとめ}

水中気泡内でパルスプラズマを並列駆動させ，難分解物 質である酢酸の分解を行った。この結果より以下のことが わかった。

（1）パルス電圧を印加した場合, 処理水の導電率が高く なることによって, 放電電流が増加した。この結果 $\mathrm{OH}$ ラジ カル生成量が増加し, 酢酸の分解がより進んだ。

（2）直流駆動方式から，パルス駆動方式にすることで放 電電極の並列化に成功した。

（３）パルス駆動方式にすることによって，9 並列電極に おいて最高分解速度は $19.8 \mu \mathrm{g} / \mathrm{min}$, 最高分解エネルギー効 率は, $0.35 \mathrm{~g} / \mathrm{kWh}$ となり, 直流放電時の約 46 倍の分解エネ ルギー効率が得られた。

本研究は文部科学省科学研究費補助金によって進められ た。

(平成 19 年 6 月 22 日受付，平成 20 年 1 月 18 日再受付)

\section{文献}

(1) R. Sankaranarayanan, B. Pashaie, and S. K. Dhali : "Laser-induced fluorescence of $\mathrm{OH}$ radicals in a dielectric barrier discharge", Appl. Phys. Lett., Vol.77, pp.2970-2972 (2000)

(2) M. A. Malik, A. Ghaffar, and S. A. Malik : "Water purification by electrical discharges", Plasma Sources Sci. Technol., Vol.10, pp.82-91 (2001)

( 3 ) M. Sato, T. Ohgiyama, and J. S. Clements : "Formation of Chemical Species and Their Effects on Microorganisms Using a Pulsed High-Voltage Discharge in Water", IEEE Trans. Ind. Appl., Vol.32, No.1, pp.106-112 (1996)

(4) T. Miichi, N. Hayashi, S. Ihara, S. Satoh, and C. Yamabe : "Generation of Radicals using Discharge inside Bubbles in Water for Water Treatment", Ozone-Sci. Eng., Vol.24, pp.471-477 (2002)

(5) M. Kurahashi, S. Katsura, and A. Mizuno : "Radical formation due to discharge inside bubble in liquid", J. Electrostat., Vol.42, pp.93-105 (1997)

(6) N. Sano, D. Yamamoto, T. Kanki, and A. Toyoda : "Decomposition of Phenol in Water by Cylindrical Wetted-Wall Reactor Using Direct Contact of Gas Corona Discharge", Ind. Eng. Chem. Res., Vol.42, No.22, pp.5423-5428 (2003)
( 7 ) T. Iijima, Y. Okita, K. Kubo, R. Makise, and T. Murata : "New Oxidation Technology by Using OH Radical with Long Lifetime in Plasma", Proc. 17th World Ozone Congress, IV.2.7, pp.1-11 (2005)

(8) A. Yamatake, J. Fletcher, K. Yasuoka, and S. Ishii : "Water Treatment by Fast Oxygen Radical Flow with DC Driven Micro-Hollow Cathode Discharge", IEEE Trans. Plasma Sci., pp.1375-1381 (2006)

(9) B. Sun, M. Sato, and J. S. Clements : "Optical study of active species produced by a pulsed streamer corona discharge in water", J. Electrostatic, Vol.39, pp.189-202 (1997)

(10) 水ハンドブック, p.318, 丸善 (2003)

(11) F. Tochikubo, S. Uchida, and T. Watanabe : "Study on Decay Characteristics of OH Radical Density in Pulsed Discharge in Ar/H2O", Jpn. J. Appl. Phys., Vol.43, No.1, pp.315-320 (2004)

(12) C. Lee, D. B. Graves, M. A. Lieberman, and D. W. Hess : "Global-Model of Plasma Chemistry in a High-Density Oxygen Discharge", $J$. Electrochem. Soc., Vol.141, No.6, pp.1546-1555 (1994)

(13) R. Peyrous, P. Pignolet, and B. Held : "Kinetic simulation of gaseous species created by electrical discharge in dry or humid oxygen", J. Phys. D : Appl. Phys., Vol.22, pp.1658-1667 (1989)

(14) R. Atkinson, D. L. Baulch, R. A. Cox, R. F. Hampson, Jr., J. A. Kerr, and J. Troe : "Evaluated Kinetic and Photochemical Data for Atmospheric Chemistry: Supplement III. IUPAC Subcommittee on Gas Kinetic Data Evaluation for Atmospheric Chemistry", J. Phys. Chem. Ref. Data, Vol.18, p.881 (1989)

(15) D. L. Baulch, C. J. Cobos, R. A. Cox, C. Esser, P. Frank, Th. Just, J. A. Kerr, M. J. Troe, R. W. Walker, and J. Warnatz : "Evaluated Kinetic Data for Combustion Modelling", J. Phys. Chem. Ref. Data, Vol.21, p.411 (1992)

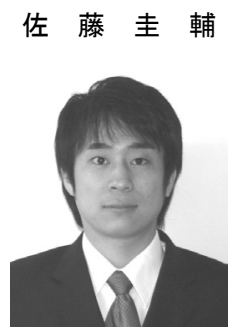

(学生員) 1983 年 7 月 2 日生。 2006 年 3 月東 京工業大学工学部電気電子工学科卒業。同年 4 月同大学大学院理工学研究科電気電子工学専 攻入学, 現在に至る。主に, プラズマを用いた 水処理の研究に従事。

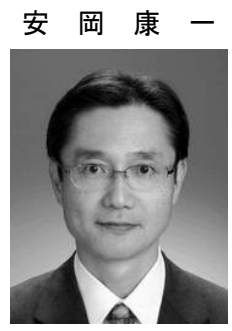

（正員） 1955 年 9 月 22 日生。1983 年 3 月東 京工業大学大学院博士課程修了。同年（株）東 芝入社。1 995 年東京工業大学助教授を経て 2007 年教授。現在に至る。大気圧プラズマ, EHD 研 究に従事。工学博士。IEEE, 応用物理学会, 静 電気学会，オゾン協会会員。

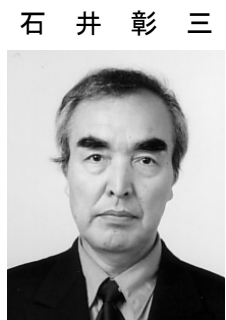

（正員） 1945 年 12 月 16 日生。1973 年 3 月東 京工業大学大学院理工学研究科電気工学専攻 博士課程修了。同年 4 月東京工業大学工学部助 手, 助教授を経て, 1990 年教授, 現在に至る。 主として，気体・液体・固体を用いたマイクロ プラズマの研究に従事。工学博士。応用物理学 会, IEEE 会員。 